\title{
Thioredoxin is essential for Rhodobacter sphaeroides growth by aerobic and anaerobic respiration
}

\author{
Cécile Pasternak, ${ }^{1} \dagger$ Karine Assemat, ${ }^{1} \ddagger$ Jenny D. Clément-Métral' \\ and Gabriele Klug ${ }^{2}$
}

1 Laboratoire de

Technologie Enzymatique, URA 1442 du CNRS, Université de Technologie de Compiègne, BP 649 60206 Compiègne Cedex, France

2 Institut für Mikrobiologie und Molekularbiologie, Frankfurter Strasse 107, 35392 Giessen, Germany Author for correspondence: Gabriele Klug. Tel: +49641 7029652. Fax: +49641 7029659.
e-mail: Gabriele.Klug@mikro.bio.uni-giessen.de

To investigate the biological role of thioredoxin in the facultative photosynthetic bacterium Rhodobacter sphaeroides, attempts were made to construct a thioredoxin-deficient mutant by site-specific mutagenesis, using the Tn903 kanamycin resistance gene for selection. In situ and Southern hybridization analyses have demonstrated that the $\operatorname{TrXA}^{-}$mutation is lethal for $R$. sphaeroides growth under anaerobic conditions with DMSO as terminal electron acceptor and under aerobic conditions. In addition, the DNA region upstream of the trxA initiation codon is essential for aerobic growth of $R$. sphaeroides. An ORF of unknown function was identified in this region and is suggested to encode a product essential for aerobic metabolism of $\boldsymbol{R}$. sphaeroides. The mechanism of thioredoxin action was also analysed by using the procedure for gene replacement to introduce a Cys33 to Ser mutation into the trxA chromosomal copy. The strain carrying this mutation produced a thioredoxin impaired in its protein-disulfide reductase activity and was also not viable. These data suggest that the physiological function of $R$. sphaeroides thioredoxin is redox-dependent. Thioredoxin purified from $R$. sphaeroides was shown to have a glutathione-disulfide oxidoreductase activity typical of glutaredoxins. This unexpected finding suggests that $R$. sphaeroides thioredoxin, in contrast to Escherichia coli thioredoxin, has the potential to act in GSH-dependent processes. Thus, the fundamental role of $R$. sphaeroides thioredoxin in cell growth probably originates from the multiple functions it can serve in vivo.

Keywords: Rhodobacter sphaeroides, thioredoxin, site-specific mutagenesis, disulfide oxidoreductase activity

\section{INTRODUCTION}

Thioredoxins are widely distributed small proteins containing an extremely reactive dithiol-disulfide in their active site. These proteins are assumed to regulate many biological processes by thiol redox control of target proteins, but also have non-redox functions in some protein-protein interactions (Gleason \& Holmgren, 1988; Buchanan et al., 1994).

†Present address: Institut für Mikrobiologie und Molekularbiologie, Frankfurter Strasse 107, 35392 Giessen, Germany

¥Present address: Laboratoire d'Immunologie Structurale, Institut Pasteur, 75724 Paris Cedex 15, France

The GenBank accession number for the ORF993 sequence reported in this paper is U69571.
In plants, the ferredoxin/thioredoxin system (including chloroplast thioredoxins $f$ and $m$ ) is responsible for light-mediated enzyme regulation in oxygenic photosynthesis by a selective thiol redox control (Buchanan, 1980, 1991; Cséke \& Buchanan, 1986). In addition, the chloroplast $\mathrm{m}$-type thioredoxin is essential for photosynthetic growth of the cyanobacterium Anacystis nidulans (Muller \& Buchanan, 1989).

Thioredoxin-negative mutants $\left(\operatorname{TrxA}^{-}\right)$previously isolated in Escherichia coli were viable (Holmgren et al., 1978; Russel \& Model, 1984), and the only known in vivo role of $E$. coli thioredoxin is its hydrogen donor function for methionine-sulfoxide reductase (Russel \& Model, 1986). In addition, the reduced form of E. coli thioredoxin is an essential subunit of phage T7 DNA 
polymerase (Mark \& Richardson, 1976) and is indispensable for maturation of the filamentous viruses $\mathrm{f} 1$ and M13 (Russel \& Model, 1985; Lim et al., 1985).

The NADP/thioredoxin system is also implicated in control of the division and development of eukaryotic cells. Indeed, thioredoxin is required for normal DNA synthesis in Saccharomyces cerevisiae (Muller, 1991, 1994) via a redox-dependent function (Muller, 1995) and is involved in the earliest embryonic divisions in both Drosophila (Salz et al., 1994) and Xenopus (Hartman et al., 1993). Other sites of thioredoxin action are suggested by its redox regulation of the mammalian transcription factors NF- $\kappa \mathrm{B}$ (Toledano \& Leonard, 1991; Sorachi et al., 1992; Okamoto et al., 1992; Schenk et al., 1994) and AP-1 (Abate et al., 1990; Schenk et al., 1994), and of the translational activator modulating the synthesis of photosystem II reaction centre D1 protein in Chlamydomonas reinhardtii (Danon \& Mayfield, 1994).

In addition to its regulatory activity, thioredoxin is suspected to be involved in defence against oxidative stress by its ability to reduce hydrogen peroxide (Spector et al., 1988; Mitsui et al., 1992; Tomimoto et al., 1993; Nakamura et al., 1994) and by its thiol redox control in repair of oxidatively inactivated proteins (Fernando et al., 1992; Natsuyama et al., 1992). Thioredoxin has also been reported to act as the physiological hydrogen donor for the antioxidant activity of yeast peroxidase (Chae et al., 1994).

The purple non-sulfur bacterium Rhodobacter sphaeroides is an extremely versatile organism capable of growth by aerobic and anaerobic respiration in the dark, by fermentation, and by anoxygenic photosynthesis in the light. Synthesis of its photosystem is known to be tightly regulated by oxygen tension (Kiley \& Kaplan, 1988 ). In $R$. sphaeroides, thioredoxin was originally characterized by its ability to regulate aminolaevulinic acid synthase (the first enzyme of the branched bacteriochlorophyll and haem biosynthetic pathway) activity in vitro by a dithiol-disulfide exchange (Clément-Métral, 1979), suggesting that thioredoxin may be involved in oxygen regulation of bacteriochlorophyll biosynthesis at a post-translational level by thiol redox control (Clément-Métral, 1986). The single thioredoxin-encoding gene $(\operatorname{tr} x A)$ of $R$. sphaeroides has been isolated and sequenced (Pille et al., 1990). Expression analyses have demonstrated that $R$. sphaeroides thioredoxin can replace $E$. coli thioredoxin as hydrogen donor for methionine-sulfoxide reductase, as a subunit of phage T7 DNA polymerase and in assembly of filamentous M13 phage (Pille et al., 1990). More precisely, Gly74 of $R$. sphaeroides thioredoxin was shown to have a direct role in the binding of T7 gene 5 protein (Pille et al., 1996). In addition, we have recently demonstrated that transcription of the $R$. sphaeroides trx $A$ gene is oxygenregulated, with increased expression under high oxygen tension, suggesting possible involvement of thioredoxin in defence against oxidative stress in this organism (Pasternak et al., 1996).
To investigate the biological function of thioredoxin in $R$. sphaeroides, we have attempted to construct a thioredoxin-deficient mutant. Our results indicate that this mutation is lethal for $R$. sphaeroides growth by anaerobic respiration in the presence of DMSO or by aerobic respiration. In addition, the DNA region upstream of the $\operatorname{tr} x A$ gene is essential for aerobic growth but not for anaerobic respiration. Surprisingly, homogeneous $R$. sphaeroides thioredoxin exhibits some GSHdisulfide oxidoreductase activity, which may explain why it is essential for growth of $R$. sphaeroides.

\section{METHODS}

Materials. 2-Hydroxyethyl disulfide was obtained from Aldrich; NADPH, GSH and yeast GSH reductase from Sigma ; and E. coli thioredoxin from Promega. E. coli glutaredoxins (Grx1 and Grx3) were a gift from Professor Arne Holmgren (Karolinska Institute, Stockholm, Sweden). R. sphaeroides thioredoxin was expressed and purified as described previously (Assemat et al., 1995).

Bacterial strains, plasmids and growth conditions. Bacterial strains and plasmids used in this study are listed in Table $1 . R$. sphaeroides strains were grown in YCC rich medium (Sistrom, 1977), supplemented with appropriate antibiotics when necessary. Anaerobic dark growth was achieved using $20 \mathrm{mM}$ dimethyl sulfoxide as the terminal electron acceptor and $0.25 \%(\mathrm{w} / \mathrm{v})$ glucose in completely filled screw-cap tubes for liquid cultures and by using Anaerocults (Merck) for agar plates. E. coli strains were grown aerobically at $37^{\circ} \mathrm{C}$ in Luria-Bertani (LB) medium (Maniatis et al., 1982). Antibiotics were added to growth media at the following concentrations: ampicillin (Ap) $200 \mu \mathrm{g} \mathrm{ml}^{-1}$ in LB; tetracycline (Tc) $10 \mu \mathrm{g} \mathrm{ml}^{-1}$ in $\mathrm{LB}, 1.5 \mu \mathrm{g} \mathrm{ml}^{-1}$ in YCC; kanamycin $(\mathrm{Km}) 100 \mu \mathrm{g} \mathrm{ml}^{-1}$ in LB, $20 \mu \mathrm{g} \mathrm{ml}^{-1}$ in YCC; streptomycin (Sm) $25 \mu \mathrm{g} \mathrm{m}^{-1}$ in YCC.

Bacterial mating. Plasmid DNA was mobilized into $R$. sphaeroides strains by diparental conjugation with $E$. coli SM10 as the donor (Simon et al., 1983). Filter matings were performed on YCC plates by incubating for $15 \mathrm{~h}$ at $37^{\circ} \mathrm{C}$ [the optimal temperature of conjugation for the $R$. sphaeroides WS8 recipient strain (Table 1 )], using a cell ratio of $\approx 1 \times 10^{9}$ late-exponential-phase chemoheterotrophically grown recipients to $\approx 5 \times 10^{7}$ early-exponential-phase donors per mating. The mating mixtures were removed from the filters, washed once in YCC medium and spread on YCC plates containing appropriate antibiotics.

Molecular biological techniques. Plasmids and DNA fragments were isolated, treated with modifying enzymes and electrophoretically analysed by standard techniques (Maniatis et al., 1982). Sequencing was performed by the dideoxy technique using the T7 sequencing kit (Pharmacia). Sitedirected mutagenesis was performed as described elsewhere (Pille et al., 1996).

Chromosomal DNA from $R$. sphaeroides was isolated by an alkaline lysis procedure (Davis et al., 1980). Samples of DNA were electrophoresed on a $0.7 \%(\mathrm{w} / \mathrm{v})$ agarose gel, blotted onto nylon membranes (NY 13, Schleicher \& Schull) by vacuum pressure (Vacuum Blotting, Pharmacia) following the manufacturer's instructions and used for Southern hybridization. For in situ hybridization, $R$. sphaeroides colonies were picked from appropriate antibiotic-supplemented plates and smeared onto a nylon membrane. After incubating the membranes for $24 \mathrm{~h}$ at $32{ }^{\circ} \mathrm{C}$, these membranes were placed on 3MM Whatman paper presoaked in lysis buffer (Davis et al., 
Table 1. Bacterial strains and plasmids

\begin{tabular}{|c|c|c|}
\hline Strain or plasmid & Relevant characteristic(s) & Source or reference \\
\hline \multicolumn{3}{|l|}{ Strains } \\
\hline \multicolumn{3}{|l|}{ E. coli } \\
\hline HB101 & $\begin{array}{l}\text { supE44 hsdS20 }\left(\mathrm{r}_{\mathrm{B}}^{-}, \mathrm{m}_{\mathrm{B}}^{-}\right) \text {recA13 ara-14 proA2 lacY1 galK2 rpsL20 } \\
\text { xyl-5mtl-1 }\end{array}$ & Bolivar \& Backman (1979) \\
\hline SM10 & recA thi thr leu; chromosomal RP4-2 (Tc:: Mu) $\mathrm{Tra}^{+} \mathrm{Km}^{\mathrm{R}}$ & Simon et al. (1983) \\
\hline \multicolumn{3}{|l|}{ R. sphaeroides } \\
\hline WS8 & Wild-type & Sistrom (1977) \\
\hline WSm & WS8 derivative, $\mathrm{Sm}^{\mathrm{R}}$ (spontaneous) & This study \\
\hline \multicolumn{3}{|l|}{ Plasmids } \\
\hline pUC18 & $\mathrm{Ap}^{\mathrm{R}}$, MCS from M13mp19 into lac $Z^{\prime}$ & Yanisch-Perron et al. (1985) \\
\hline pSUP203 & pBR325 derivative, $\mathrm{Mob}^{+} \mathrm{Ap}^{\mathrm{R}} \mathrm{Cm}^{\mathrm{R}} \mathrm{Tc}^{\mathrm{R}}$ & Simon et al. (1983) \\
\hline pUC4KSAC & $\mathrm{Ap}^{\mathrm{R}}$, source of the $\mathrm{Km}^{\mathrm{R}}$ cassette & Barany $(1985)$ \\
\hline pUTC3 & 421 bp NcoI-PstI trxA fragment in pKK233-2 & Pille et al. (1990) \\
\hline pUTC66 & $2.9 \mathrm{~kb}$ EcoRI trxA fragment in pUC18 & This study \\
\hline pUTC76 & $2 \cdot 1 \mathrm{~kb}$ EcoRI $\operatorname{tr} x A$ fragment in pUC18 & This study (Fig. 1) \\
\hline pUTC84 & pUTC76:: $\mathrm{Km}^{\mathrm{R}}$ cassette ligated into $B g l$ II site of $t r x A$ fragment & This study \\
\hline pUTC78 & pUTC76:: $\mathrm{Km}^{\mathrm{R}}$ cassette ligated into SacI site of $t r x A$ fragment & This study \\
\hline pUTC92 & pUTC76:: $\mathrm{Km}^{\mathrm{R}}$ cassette ligated into BamHI site of $t r x A$ fragment & This study \\
\hline pUTC98 & pUTC76, trxA Cys33 to Ser mutation & This study \\
\hline pUTC100 & pUTC $98:: \mathrm{Km}^{\mathrm{R}}$ cassette ligated into BamHI site of $t r x A$ fragment & This study \\
\hline pUTC80 & pSUP203::3.4 kb EcoRI trxA $\Omega \mathrm{Km}^{\mathrm{R}}$ fragment from pUTC78 & This study (Fig. 1) \\
\hline pUTC86 & pSUP203::3.4 kb EcoRI $t r x A \Omega \mathrm{Km}^{\mathrm{R}}$ fragment from pUTC84 & This study (Fig. 1) \\
\hline pUTC97 & 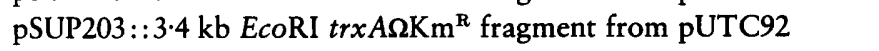 & This study (Fig. 1) \\
\hline pUTC101 & pSUP203::3.4 kb EcoRI trxA $\Omega \mathrm{Km}^{\mathrm{R}}$ fragment from pUTC100 & This study (Fig. 1) \\
\hline
\end{tabular}

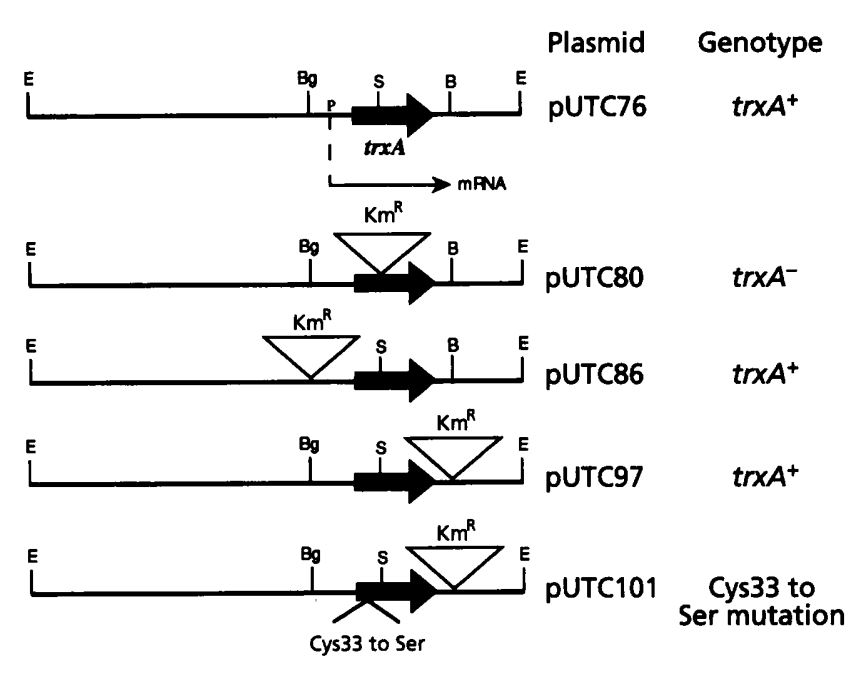

Fig. 1. $\mathrm{Km}$ resistance cartridge insertions into the trxA region. Lines indicate DNA fragments in the trxA region which were ligated into pUC18 or pSUP203 to form the designated plasmids (Table 1). Insertions of the Tn903 cartridge (Barany, 1985) conferring $\mathrm{Km}$ resistance are shown and the trxA genotype corresponding to the resulting plasmid is indicated. The Cys 33 to Ser mutation of trxA gene on pUTC101 was introduced by site-directed mutagenesis as described in Methods. Restriction enzymes used were BamHI (B), Bg/II (Bg), EcoRI (E) and Sacl (S).

1980). After $15 \mathrm{~min}$, membranes were transferred into $0.5 \mathrm{M}$ $\mathrm{NaOH}, 1.5 \mathrm{M} \mathrm{NaCl}$ for $2 \times 15 \mathrm{~min}$ and neutralized with $1 \mathrm{M}$ Tris/ $\mathrm{HCl} \mathrm{pH} \mathrm{7.5,} \mathrm{1.5} \mathrm{M} \mathrm{NaCl} \mathrm{for} \mathrm{the} \mathrm{same} \mathrm{time.} \mathrm{Filters} \mathrm{were}$ then washed in $2 \times$ SSC (Maniatis et al., 1982) for $5 \mathrm{~min}$ and dried. DNA was cross-linked onto nylon membranes by UV irradiation (Stratalinker, Stratagene). Unbound material was removed by washing in $3 \times \mathrm{SSC}, 0.1 \%(\mathrm{w} / \mathrm{v}) \mathrm{SDS}$ at $50^{\circ} \mathrm{C}$ for $3 \mathrm{~h}$. Non-radioactive DNA probes using DIG*-dUTP were made and utilized according to the manufacturer's instructions with the random-primed DNA Labeling Kit (Boehringer Manheim). The labelled probes were detected either by colorimetric reaction or preferentially by chemiluminescent reaction when membranes needed to be reprobed.

Insertions of the $\mathrm{Km}$ resistance cartridge into the trXA gene region. The $2.9 \mathrm{~kb} E c o \mathrm{RI}$ fragment containing the $\operatorname{tr} x A$ gene region was first isolated from the $R$. sphaeroides $\lambda E M B L 3$ genomic library constructed previously (Pille et al., 1990) and cloned into pUC18, yielding the plasmid pUTC66 (Table 1). To facilitate subsequent genetic analyses, several subcloning steps were performed to generate plasmid pUTC76, a pUC18 derivative containing a $2 \cdot 1 \mathrm{~kb} E$ coRI trx $A$ fragment (Table 1 ; Fig. 1). The Tn903 Km resistance cartridge of pUC4KSAC (Barany, 1985) was then inserted into the $\operatorname{tr} x A$ fragment of pUTC76 at three different sites: the $B g l$ II site located $174 \mathrm{bp}$ upstream of the $\operatorname{tr} x A$ initiation codon, the $S a c$ I site of the $\operatorname{tr} x A$ coding region and the $B a m H I$ site located 90 bp downstream of the $\operatorname{tr} x A$ stop codon, generating pUTC84, pUTC78 and pUTC92, respectively. In addition, the 300 bp BglII-SacI trxA fragment from pUTC76 was replaced by the corresponding restriction fragment containing the mutation Cys33 to Ser to produce pUTC 98 . The same $\mathrm{Km}$ resistance cartridge was then inserted into the Bam HI site of pUTC98 as described above, generating pUTC100 (Table 1). For subsequent transfer to $R$. sphaeroides, the four resulting insertions were then isolated as $3.4 \mathrm{~kb}$ EcoRI fragments and subcloned into the unique EcoRI site of the mobilizable pSUP203 vector (Simon et al., 1983), 
generating the plasmids pUTC86, pUTC80, pUTC97 and pUTC101, respectively (Fig. 1).

GSH-disulfide oxidoreductase assay. The assay was performed as described by Holmgren (1979), by measuring the reduction of 2-hydroxyethyl disulfide by GSH at the expense of NADPH recorded at $340 \mathrm{~nm}$. One unit (U) of activity was defined as $1 \mu \mathrm{mol}$ of NADPH oxidized per min. Purified E. coli Grx1 and Grx3 were used in each experiment as positive controls. The crude extracts used in this assay were prepared as described elsewhere (Klug, 1991). Protein concentration was determined as described by Bradford (1976).

\section{RESULTS}

\section{Disruption of the chromosomal trxA gene is lethal for both aerobic and anaerobic respiration of $R$. sphaeroides}

The biological function of $R$. sphaeroides thioredoxin was investigated by site-specific mutagenesis, using several insertions of the $\mathrm{Tn} 903 \mathrm{Km}$ resistance cassette into the cloned $t r x A$ gene region as described in Methods and shown in Fig. 1. Homologous recombination events with the genome of the $\mathrm{Sm}^{\mathrm{R}} R$. sphaeroides strain WSm (Table 1) were the result of using the mobilizable ColE1 pSUP203 plasmid (Simon et al., 1983) and directly selected by the $\mathrm{Km}$ resistance of the exconjugants.

Given that the phenotype of the $\operatorname{TrxA}^{-}$mutant was totally unknown, and since the expression of the trxA gene is regulated by oxygen (Pasternak et al., 1996), the $\mathrm{Km}^{\mathrm{R}}$ exconjugants were isolated either under aerobic conditions or under anaerobic dark conditions in the presence of DMSO as terminal electron acceptor.

Southern hybridization analyses demonstrated that the double cross-over required for integration of the $\mathrm{Km}$ resistance cassette upstream of the trxA gene (corresponding to the construct pUTC86, Fig. 1) occured in $8.1 \%$ of exconjugants selected for growth under anaerobic dark conditions (data not shown).

In contrast, gene exchange was not observed among the 614 exconjugants resulting from transfer of the pUTC80 construct (containing the disrupted trxA gene, Fig. 1) and isolated under anaerobic dark conditions. This result strongly suggests that mutants in which the chromosomal $\operatorname{tr} x A$ gene had been disrupted were not viable and that $R$. sphaeroides thioredoxin is essential for cell growth by anaerobic respiration.

Isolation of $R$. sphaeroides exconjugants under aerobic growth conditions did not allow growth of double recombinants obtained using either pUTC80 $\left(476 \mathrm{Km}^{\mathrm{R}}\right.$ exconjugants were examined) or pUTC86 plasmids. In contrast, conjugative transfer of the pUTC97 plasmid (Table 1; Fig. 1) which contains the $\mathrm{Km}$ resistance cartridge downstream of the $t r x A$ gene, provided gene replacement in $2.5 \%$ of exconjugants isolated under aerobic conditions, as deduced from both in situ and Southern hybridization analyses (data not shown). These data suggest that both the $\operatorname{tr} x A$ gene and the DNA region upstream of the BglII site (Fig. 1) are essential for $R$. sphaeroides aerobic growth.
Sequence analysis of the DNA region upstream of the trXA coding region

To define the DNA region flanking the $\mathrm{Km}$ resistance cartridge in the control plasmid pUTC86 (Fig. 1), the $\operatorname{tr} x A$ upstream region was sequenced as described in Methods. DNA sequence analysis of this region indicated the presence of an ORF, named ORF993 (Fig. 2) which has a remarkably high $\mathrm{G}+\mathrm{C}$ content of $74.6 \mathrm{~mol} \%$, given that the typical G $+C$ content of $R$. sphaeroides chromosomal DNA is $68 \%$ (Pfennig \& Truper, 1974). ORF993 shows a codon usage typical of $R$. sphaeroides, as deduced by codon preference computer program analysis, strongly suggesting that it codes for a protein. The predicted product contains 331 amino acid residues, has a predicted molecular mass of $35771 \mathrm{Da}$ and is essential for $R$. sphaeroides aerobic growth since disruption of ORF993 at the BglII site (Fig. 2 ) is lethal for aerobic respiration. This predicted protein has a remarkably high content $(43.5 \%)$ of hydrophobic residues. A putative Shine-Dalgarno ribosome-binding site (AGGTG) is located 10 nucleotides upstream of the presumed ATG initiation codon. We have not identified sequences in the GenBank database either at the nucleotide or protein level that bear significant resemblance to ORF993.

\section{The essential biological role of $\boldsymbol{R}$. sphaeroides thioredoxin may involve its oxidoreductase activity}

To determine whether the biological role of thioredoxin involves the redox properties of its active site or redoxindependent functions, we attempted to construct a $R$. sphaeroides mutant which expresses solely a thioredoxin impaired in its oxidoreductase activity, by using a gene replacement technique as described above. The Cys 33 (the second cysteine of the active site which corresponds to Cys 35 of E. coli thioredoxin) to Ser substitution was introduced by site-directed mutagenesis and the resulting mutant $\operatorname{tr} x A$ gene was used to generate the mobilizable pUTC101 plasmid as described in Methods. In this construct, the Cys33 to Ser mutation would block the protein in reduced form and should therefore abolish the oxidoreductase activity of thioredoxin. pUTC101 was transferred to the $\mathrm{Sm}^{\mathrm{R}} R$. sphaeroides strain WSm and selection of exconjugants was performed as described above.

In situ hybridization analyses of 200 exconjugants with the $\mathrm{Km}$ resistance cassette or linearized pSUP203 vector as probes demonstrated that all the colonies isolated under aerobic or anaerobic dark conditions displayed a positive signal with both probes (data not shown), indicating that they had integrated the Tn 903 gene by plasmid addition. In the control plasmid pUTC97, the $\mathrm{Km}$ resistance cartridge was inserted into the same BamHI site as in pUTC101 (Fig. 1). Since the Km resistance cassette of pUTC97 had integrated by gene replacement at a frequency of $2.5 \%$ in aerobic selection and of $3.0 \%$ in anaerobic dark selection (data not shown), the lack of double cross-over among all the exconjugants resulting from pUTC101 transfer was not 


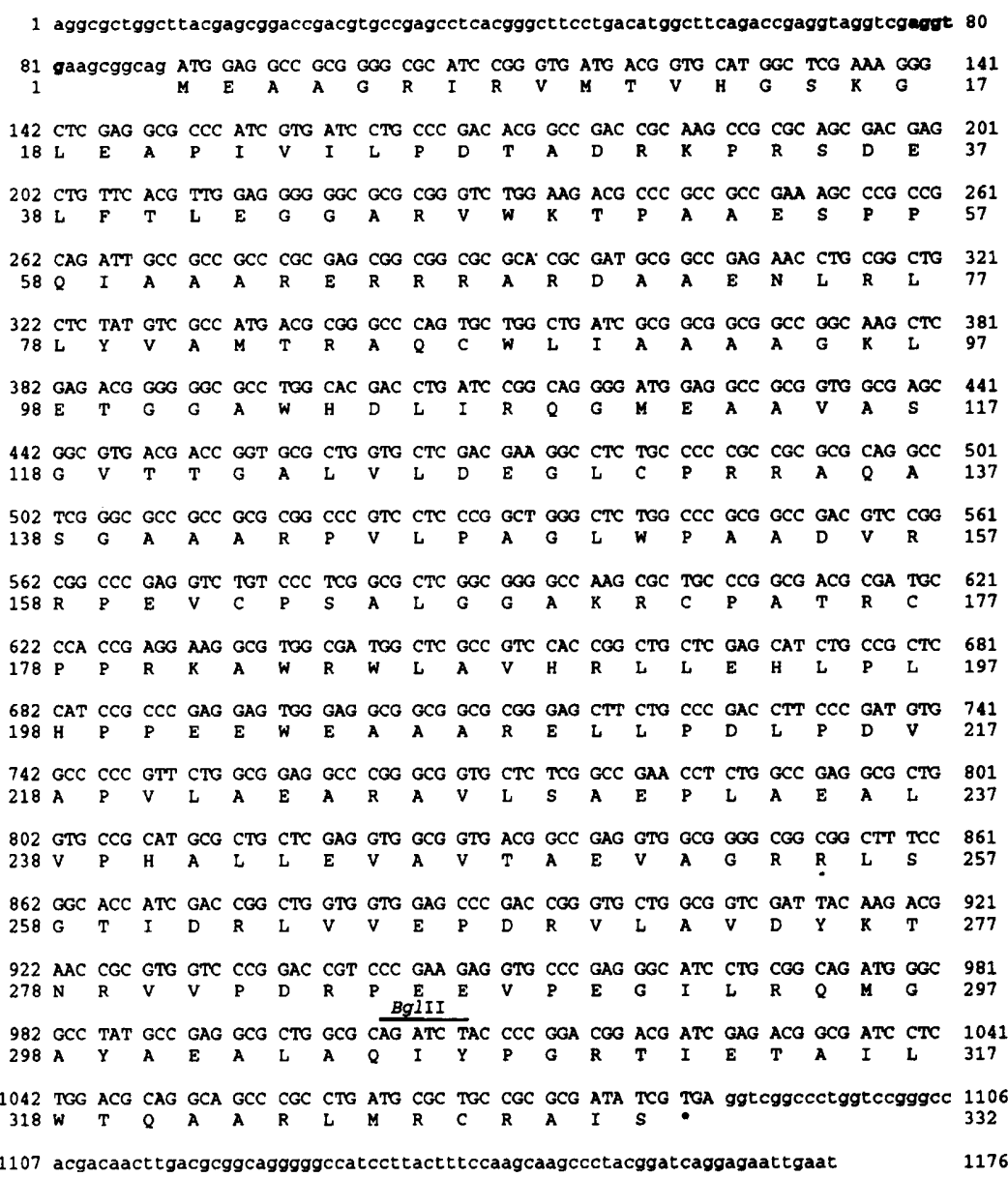

81 gaageggcag ATG GAG GCC GCG GGG CGC ATC CGG GTG ATG ACG GTG CAT GGC TCG AAA GGG 141 142 CTC GAG GCG CCC ATC GTG ATC CTG CCC GAC ACG GCC GAC CGC AAG CCG CGC AGC GAC GAG 201

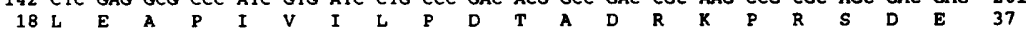

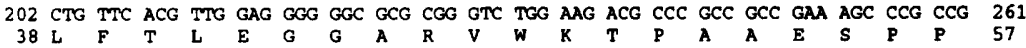
262 CAG ATT GCC GCC GCC CGC GAG CGG CGG CGC GCA CGC GAT GCG GCC GAG AAC CTG CGG CTG 321 322 CTC TAT GTC GCC ATG ACG CGG GCC CAG TGC TGG CTG ATC GCG GCG GCG GCC GGC AAG CTC 381

442 GOC GTG ACG ACC GGT GCO TTO

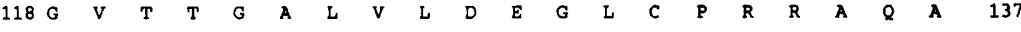
502 TCG GGC GCC GCC GCG CGG CCC GTC CTC CCG GCT GGG CTC TGG CCC GCG GCC GAC GTC CGG 561 562 CGG CCC GAG GTC TGT CCC TCG GCG CTC GGC GGG GCC AAG CGC TGC CCG GCG ACG CGA TGC 621

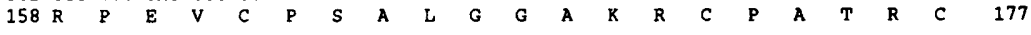

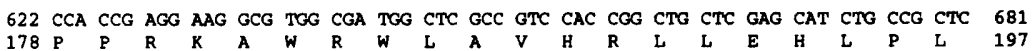
682 CAT CCG CCC GAG GAG TGG GAG GCG GCG GCG CGG GAG CTT CTG CCC GAC CTT CCC GAT GTG 741

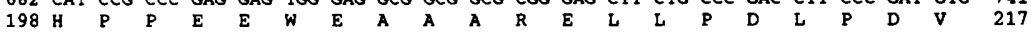
742 GCC CCC GTT CTG GCG GAG GCC CGG GCG GTG CTC TCG GCC GAA CCT CTG GCC GAG GCG CTG 801

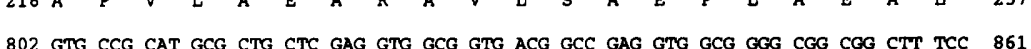

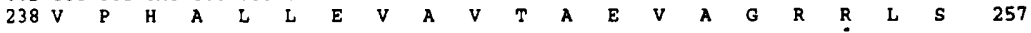
862 GGC ACC ATC GAC CGG CTG GTG GTG GAG CCC GAC CGG GTG CTG GCG GTC GAT TAC AAG ACG 921 258 G

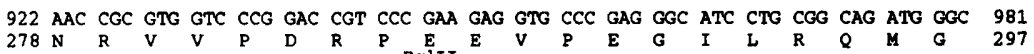
982 GCC TAT GCC GAG GCG CTG GCG CAG ATC TAC CCC GGA CGG ACG ATC GAG ACG GCG ATC CTC 1041 1042 TGG ACG CAG SCA GCC CGC CTG ATG CGC TGC CGC GCG ATA TCG TGA ggteggecetggeccgggec 1106 1107 acgacaacttgacgcggcagggggccatccttactttccaagcaagcctacggatcaggagaattgaat
Fig. 2. Nucleotide and deduced amino acid sequence of ORF993, preceding the trxA gene in the chromosome of $R$. sphaeroides. The possible ribosome-binding site is indicated in bold type. The stop codon is indicated by an asterisk. The Bg/ll restriction site in which the $\mathrm{Km}$ resistance cartridge was inserted in the construct pUTC86 (Fig. 1) is shown. The trxA coding region starts at position 1177. due to physical constraint of homologous DNA flanking the cassette present in this construct. More likely, cells in which the Cys33 to Ser mutation has been introduced into the chromosomal $\operatorname{tr} x A$ copy by gene replacement are not viable, suggesting that the physiological function of $R$. sphaeroides thioredoxin is redox-dependent.

\section{R. sphaeroides thioredoxin has GSH-disulfide oxidoreductase activity}

GSH-disulfide oxidoreductase (or transhydrogenase) activity is an inherent property of glutaredoxin (Holmgren, 1979). E. coli contains three species of GSH transhydrogenase activity corresponding to Grx1, the first glutaredoxin discovered (Holmgren, 1979) and two other proteins that were identified more recently and therefore called Grx2 and Grx3 (Åslund et al., 1994, 1996). To examine whether or not $R$. sphaeroides contains glutaredoxin-like system(s), we tested crude extracts from aerobic cultures of the $R$. sphaeroides WS8 wild-type strain in a GSH oxidoreductase assay. The results of these experiments are summarized in Table 2. E. coli Grx1 and Grx3 were used as positive controls and were found to have a specific activity of 106 and $156 \mathrm{U}$ (mg protein $)^{-1}$, respectively. These results are in agreement with the values previously reported (Holmgren, 1979; Åslund et al., 1994) and therefore argue for the validity of our experimental conditions.
Surprisingly, $R$. sphaeroides thioredoxin purified to homogeneity was demonstrated to have an inherent GSH transhydrogenase activity of $10 \mathrm{U}$ (mg protein) ${ }^{-1}$ (Table 2), whereas E. coli thioredoxin lacked such activity (Table 2) as previously reported (Holmgren, 1978). However, most of the total GSH-disulfide oxidoreductase activity in the crude extract of $R$. sphaeroides was apparently unrelated to thioredoxin (Table 2). Indeed, given that the intracellular amount of thioredoxin in $R$. sphaeroides was previously estimated to be $0.24 \mu \mathrm{g}$ (mg protein) ${ }^{-1}$ (Clément-Métral et al., 1986), approximately $1.8 \%$ of the GSH transhydrogenase activity in a crude extract of $R$. sphaeroides can be attributed to thioredoxin. Analysis of heated $\left(80^{\circ} \mathrm{C}\right.$ for $10 \mathrm{~min}$ ) crude extracts after separation of heat-denatured proteins by centrifugation has shown that the specific GSH transhydrogenase activity of $R$. sphaeroides was enriched by approximately fivefold, while it was almost unchanged for $E$. coli (Table 2). These results indicate that the major species responsible for this activity in $R$. sphaeroides behave as heat-stable products (a property which is common to thioredoxin and Grx1), but that some of the species responsible for this activity in E. coli are denatured by heat. In addition, purified thioredoxin of $R$. sphaeroides submitted to this heat treatment retained all its GSH transhydrogenase activity (Table 2). The bacterial extracts previously heated were then submitted to an overnight dialysis 
Table 2. Assay of GSH-disulfide oxidoreductase activity

\begin{tabular}{|c|c|}
\hline Material & $\begin{array}{c}\text { GSH-disulfide } \\
\text { oxidoreductase activity } \\
{\left[\mathrm{U}(\mathrm{mg} \text { protein })^{-1}\right]^{*}}\end{array}$ \\
\hline \multicolumn{2}{|l|}{ Purified protein $\dagger$} \\
\hline E. coli Grx1 & 106 \\
\hline E. coli Grx3 & 156 \\
\hline E. coli $\operatorname{Tr} \mathbf{x}$ & 0 \\
\hline E. coli $\operatorname{Trx} \ddagger$ & 0 \\
\hline E. coli $\operatorname{Trx} \$$ & 0 \\
\hline R. sphaeroides $\operatorname{Trx} \|$ & 10 \\
\hline R. sphaeroides Trx $\neq$ & 10 \\
\hline R. sphaeroides $\operatorname{Trx} \rrbracket$ & 0 \\
\hline \multicolumn{2}{|l|}{ Crude extract } \\
\hline \multicolumn{2}{|l|}{ From $E$. coli } \\
\hline 19 & $1 \cdot 5$ \\
\hline $2 \ddagger$ & 1.42 \\
\hline $3 \neq \mathbb{S}$ & 0.58 \\
\hline \multicolumn{2}{|l|}{ From $R$. sphaeroides } \\
\hline 19 & $0 \cdot 133$ \\
\hline $2 \ddagger$ & 0.633 \\
\hline $3 \neq \$$ & 0.094 \\
\hline
\end{tabular}

* GSH transhydrogenase activity was determined as described in Methods. In the assays, three different concentrations of proteins or extracts were used and all experiments were performed at least twice.

† Grx, glutaredoxin; Trx, thioredoxin.

$\ddagger$ Crude extracts or purified proteins were heated to $80^{\circ} \mathrm{C}$ for $10 \mathrm{~min}$. In crude extracts the resulting precipitate was removed by centrifugation to give a clear supernatant.

$\$$ Crude extracts or purified proteins were dialysed overnight against $25 \mathrm{mM}$ Tris $/ \mathrm{HCl} \mathrm{pH} 8,5 \mathrm{mM}$ EDTA, $15 \mathrm{mM} \mathrm{NaN}_{3}$, $50 \mathrm{mM} \mathrm{NaCl}$, so that compounds of molecular mass equal to or smaller than $12-14 \mathrm{kDa}$ were removed.

$\|$ The thioredoxin of $R$. sphaeroides was purified as described in Methods.

S Crude extracts were prepared as described in Methods.

(which removes components of molecular mass equal to or less than $12-14 \mathrm{kDa}$ ). The resulting samples retained approximately $15 \%$ of the specific GSH transhydrogenase activity for $R$. sphaeroides and $40 \%$ for $E$. coli (Table 2). In control experiments, purified thioredoxin of $R$. sphaeroides $(10.8 \mathrm{kDa})$ and $E$. coli $(11.7 \mathrm{kDa})$ were submitted to the same dialysis treatment. Determination of the protein concentrations of the resulting samples (data not shown) indicated that almost all of the thioredoxin protein from both microorganisms is removed through dialysis and no more GSH-disulfide oxidoreductase activity was detected for the dialysed sample of $R$. sphaeroides thioredoxin (Table 2). These results provide evidence that most of the components with a molecular mass less than 12-14 kDa were also removed from the cell-free extracts after dialysis. The remaining $(40 \%)$ GSH transhydrogenase activity in E. coli after dialysis indicates that the major species responsible for GSH-disulfide oxidoreductase activity has a molecular mass greater than $14 \mathrm{kDa}$. This finding is consistent with the recent identification of an atypical glutaredoxin in E. coli, Grx2 $(27 \mathrm{kDa})$ with a relative contribution to the GSH transhydrogenase activity of $81.4 \%$ (Åslund et al., 1994). In contrast, $85 \%$ of the specific activity in $R$. sphaeroides was lost after dialysis, indicating that most of the GSH transhydrogenase activity is due to species with a molecular mass less than $12-14 \mathrm{kDa}$.

\section{DISCUSSION}

To investigate the contribution of thioredoxin to the regulation of photosynthetic metabolism, we attempted to construct a $R$. sphaeroides TrxA mutant by gene replacement. From a series of experiments which examined integration of the $\mathrm{Tn} 903 \mathrm{Km}$ resistance gene into different sites of the $\operatorname{tr} x A$ region, we have demonstrated that disruption of the unique chromosomal trxA copy with a $\mathrm{Km}$ resistance cartridge is a lethal mutation. Thus, although dispensable in E. coli (Russel \& Model, 1984), thioredoxin is absolutely required for both aerobic and anaerobic respiration of the facultative photosynthetic bacterium $R$. sphaeroides.

To examine whether the mechanism of thioredoxin action is redox-dependent, we attempted to produce a mutant strain which expresses a thioredoxin altered in its protein-disulfide reductase activity due to a Cys 33 to Ser substitution. This experiment showed that such a mutant is also not viable, suggesting that the biological involvement of $R$. sphaeroides thioredoxin requires its redox properties. The lack of double cross-over in the DNA region downstream of the Cys33 codon after conjugative transfer of the pUTC101 construct (which would generate a wild-type $\operatorname{trx} A$ chromosomal copy followed by $\mathrm{Km}$ resistance cassette insertion into the downstream BamHI site as observed for $2.5-3.0 \%$ of exconjugants provided by transfer of the pUTC 97 control construct) is most probably due to the length of the sequence between the Cys 33 codon and the Bam HI site of $\mathrm{Km}$ insertion (only $300 \mathrm{bp}$ ), for which the gene exchange frequency is expected to be very low.

In addition, the fact that insertion of the $\mathrm{Km}$ resistance cassette into the BglII site at $174 \mathrm{bp}$ upstream of the trxA coding region (pUTC86 construct; Fig. 1) was obtained by gene exchange only after selection under anaerobic dark conditions (with a frequency of $8.1 \%$ ) but not after selection under aerobic conditions suggests that this region is essential for aerobic metabolism but not for anaerobic metabolic pathways using DMSO as terminal electron acceptor. Since the regulatory sequences required for oxygen-regulated expression of $\operatorname{trx} A$ are localized downstream of the BglII site (Pasternak et al., 1996) and since a construct containing only $100 \mathrm{bp}$ upstream of $\operatorname{tr} x A$ coding region is sufficient to replace $E$. coli thioredoxin for in vivo hydrogen donor function for methionine-sulfoxide reductase (data not shown), it is unlikely that insertion of the $\mathrm{Km}$ resistance cassette into BglII would interrupt cis-acting regulatory sequences 
involved in oxygen regulation of $\operatorname{tr} x A$ gene expression. More likely, the insertion of the $\mathrm{Km}$ resistance gene into the BgllI site could disrupt another gene encoding a product essential for aerobic respiration but not for anaerobic respiration. Indeed, an ORF (ORF993) which flanks the $\mathrm{Km}$ resistance cassette in the pUTC86 construct has been identified, but this shows no significant homology to any known genes and its function remains to be determined.

In other respects, $R$. sphaeroides thioredoxin purified to homogeneity was shown to have an inherent GSHdisulfide oxidoreductase activity, which is a feature of glutaredoxins (Holmgren 1979; Åslund et al., 1994). This unexpected property of $R$. sphaeroides thioredoxin differentiates it from $E$. coli thioredoxin which lacks such activity (Holmgren, 1978) and may indicate that $R$. sphaeroides thioredoxin has some function(s) that it does not have in E. coli (i.e. participation in GSHdependent processes).

In $E$. coli, the viability of the double mutant lacking thioredoxin and Grx1 (Russel et al., 1990 ; MirandaVizuete et al., 1994) provided evidence of a functional redundancy of the enzyme systems for reduction of the ribonucleotide reductase, and the recently discovered Grx3 is likely to be an alternative hydrogen donor in the ribonucleotide reduction reaction in the double mutant (Åslund et al., 1994). The apparent level of total GSH oxidoreductase activity is 10 -fold lower in $R$. sphaeroides than in E. coli (Table 2) and is exclusively due to small species having a molecular mass lower than $14 \mathrm{kDa}$, while in E. coli, about $40 \%$ of the total activity involves species with a molecular mass greater than $14 \mathrm{kDa}$. These results suggest a lower abundance of hypothetical alternative redox activity such as glutaredoxin sytems in $R$. sphaeroides. However, most of the GSH transhydrogenase activity of $R$. sphaeroides is not related to thioredoxin, suggesting that additional glutaredoxin-like systems are also present in $R$. sphaeroides. In vitro, thioredoxin and glutaredoxins serve as hydrogen donors for ribonucleotide reductase (Gleason \& Holmgren, 1988), which is essential for DNA synthesis. Thus, thioredoxin may be essential in $R$. sphaeroides for deoxyribonucleotide synthesis. Given the reactivity of $R$. sphaeroides thioredoxin with the GSH-system as shown by our experiment (Table 2), the thioredoxin may use either thioredoxin reductase or GSH as reduction pathways to couple oxidation of NADPH to reduction of ribonucleotides in $R$. sphaeroides.

In other respects, by its general disulfide oxidoreductase activity, thioredoxin may also be essential for keeping the cysteines of cytoplasmic proteins reduced, as a control mechanism of enzyme activity like the thiol redox control exercised by thioredoxin on chloroplast enzymes of the Calvin cycle (Cséke \& Buchanan, 1986).

While the present data do not allow us to define precisely the physiological role of $R$. sphaeroides thioredoxin, they suggest several hypotheses. First, the absolute requirement of thioredoxin in oxidative metabolism of $R$. sphaeroides may reflect its implication in defence against oxidative stress, by acting in regeneration of proteins oxidatively inactivated and/or by its cellular antioxidant role as has been previously shown in other organisms. Selection of exconjugants under aerobic conditions in the presence of $1 \mathrm{mM}$ DTT did not allow us to isolate double recombinants (data not shown), indicating that the essential function of $R$. sphaeroides thioredoxin cannot be replaced by a low-molecularmass reducing agent.

During anaerobic dark growth, DMSO causes oxidation of methionine residues in methionine sulfoxide (Brot $\&$ Weissbach, 1982). In E. coli, such damage can be repaired by methionine-sulfoxide reductase (Moskovitz et al., 1995) for which the physiological hydrogen donor is thioredoxin (Russel \& Model, 1986). Thus, the lethality of $R$. sphaeroides $\operatorname{TrxA}^{-}$mutants when selected under anaerobic dark conditions suggests that thioredoxin may also be the in vivo hydrogen donor for methionine-sulfoxide reductase in $R$. sphaeroides. In other respects, based on the previous hypothesis that $R$. sphaeroides thioredoxin may be the in vivo regulator of aminolaevulinic acid (ALA) synthase activity by a thiol redox control (Clément-Métral et al., 1986), the thioredoxin negative mutants could be auxotrophic for ALA. Given that $R$. capsulatus mutant strains auxotrophic for ALA are not viable under anaerobic growth conditions in the presence of DMSO (Yen \& Marrs, 1977), we attempted to isolate the thioredoxin-deficient mutant under anaerobic dark conditions with DMSO in the presence of $1 \mathrm{mM}$ ALA (data not shown). These experiments provided the same results as those obtained for selection without supplementation with ALA, indicating that the essential function of $R$. sphaeroides thioredoxin is not related to the activation of ALA synthase.

\section{ACKNOWLEDGEMENTS}

We would like to thank Professor A. Holmgren for gifts of Grx1 and Grx3. This work was supported by Deutsche Forschungsgemeinschaft (SFB 272) and Fonds der Chemischen Industrie to G.K. C.P. was a trainee supported by a doctoral training grant from the Ministère de la Recherche et de l'Enseignement Supérieur and by a grant from the PROCOPE Program of the Ministère des Affaires Etrangères.

\section{REFERENCES}

Abate, C., Patel, L, Rauscher F. J., III \& Curran, T. (1990). Redox regulation of Fos and Jun DNA-binding activity in vitro. Science 249, 1157-1161.

Åslund, F., Ehn, B., Miranda-Vizuete, A., Pueyo, C. \& Holmgren, A. (1994). Two additional glutaredoxins exist in Escherichia coli: glutaredoxin 3 is a hydrogen donor for ribonucleotide reductase in a thioredoxin/glutaredoxin 1 double mutant. Proc Natl Acad Sci USA 91, 9813-9817.

Åslund, F., Nordstrand, K., Berndt, K. D., Nikkola, M., Bergman, T., Ponstingl, H., Jörnvall, H., Otting, G. \& Holmgren, A. (1996). Glutaredoxin-3 from Escherichia coli. J Biol Chem 271, 67366745.

Assemat, K., Alzari, P. M. \& Clément-Métral J. D. (1995). Conservative substitutions in the hydrophobic core of Rbodobacter 
sphaeroides thioredoxin produce distinct functional effects. Protein Sci 4, 2510-2516.

Barany, F. (1985). Two-codon insertion mutagenesis of plasmid genes by using single-stranded hexameric oligonucleotides. Proc Natl Acad Sci USA 82, 4202-4206.

Bolivar, F. \& Backman, K. (1979). Plasmids of Escherichia coli as cloning vectors. Methods Enzymol 68, 245-267.

Bradford, M. M. (1976). A rapid and sensitive method for quantitation of microgram quantities of protein utilizing the principle of protein-dye binding. Anal Biochem 72, 248-254.

Brot, N. \& Weissbach, H. (1982). The biochemistry of methionine sulfoxide residues in proteins. Trends Biochem Sci 7, 137-139.

Buchanan, B. B. (1980). Role of light in the regulation of chloroplast enzymes. Ann Rev Plant Physiol 31, 341-374.

Buchanan, B. B. (1991). Regulation of $\mathrm{CO}_{2}$ assimilation in oxygenic photosynthesis: the ferredoxin/thioredoxin system. Arch Biochem Biophys 288, 1-9.

Buchanan, B. B., Schurmann, P., Decottignies, P. \& Lozano, R. M. (1994). Thioredoxin: a multifunctional regulatory protein with a bright future in technology and medicine. Arch Biochem Biophys 314, 257-260.

Chae, H. Z., Chung, S. J. \& Rhee, S. G. (1994). Thioredoxindependent peroxide reductase from yeast. J Biol Chem 269, 27670-27678.

Clément-Métral, J. D. (1979). Activation of ALA synthetase by reduced thioredoxin in Rhodopseudomonas Y. FEBS Lett 101, 116-120.

Clément-Métral, J. D. (1986). Regulation of ALA synthetase by oxygen and the thioredoxin system. In Thioredoxin and Glutaredoxin Systems: Structure and Function, pp. 275-284. Edited by A. Holmgren, H. Jörnvall \& B.-M. Sjöberg. NY: Raven Press.

Clément-Métral, J. D., Hobg, J.-O. \& Holmgren, A. (1986). Characterization of the thioredoxin system in the facultative phototroph Rhodobacter sphaeroides Y. Eur J Biochem 161, 119-126.

Cséke, C. \& Buchanan, B. B. (1986). Regulation of the formation and utilization of photosynthate in leaves. Biochim Biophys Acta $853,43-63$.

Danon, A. \& Mayfield, P. (1994). Light-regulated translation of chloroplast messenger RNAs through redox potential. Science 266, 1717-1719.

Davis, R. W., Botstein, D. \& Roth, J. R. (1980). A Manual for Genetic Engineering. Advanced Bacterial Genetics. Cold Spring Harbor, NY: Cold Spring Harbor Laboratory.

Fernando, M. R., Nanri, H., Yoshitake, S., Nagata-Kuno, K. \& Minakami, S. (1992). Thioredoxin regenerates proteins inactivated by oxidative stress in endothelial cells. Eur J Biochem 209, 917-922.

Gleason, F. K. \& Holmgren, A. (1988). Thioredoxin and related proteins in procaryotes. FEMS Microbiol Rev 54, 271-298.

Hartman, H., Wu, M., Buchanan, B. B. \& Gerhart, J. C. (1993). Spinach thioredoxin $\mathrm{m}$ inhibits DNA synthesis in fertilized Xenopus eggs. Proc Natl Acad Sci USA 90, 2271-2275.

Holmgren, A. (1978). Glutathione-dependent enzyme reactions of the phage T4 ribonucleotide reductase system. J Biol Chem 253, 7424-7430.

Holmgren, A. (1979). Glutathione-dependent synthesis of deoxyribonucleotides. Purification and characterization of glutaredoxin from Escherichia coli. J Biol Chem 254, 3664-3671.

Holmgren, A., Ohlsson, I. \& Grankvist, M.-L. (1978). The thioredoxin from Escherichia coli. Radioimmunological and enzymatic determinations in wild type cells and mutants defective in phage T7 DNA replication. J Biol Chem 253, 430-436.

Kiley, P. J. \& Kaplan, S. (1988). Molecular genetics of photosynthetic membrane biosynthesis in Rhodobacter sphaeroides. Microbiol Rev 52, 50-69.

Klug, G. (1991). A DNA sequence upstream of the puf operon of Rhodobacter capsulatus is involved in its oxygen-dependent regulation and functions as a protein binding site. Mol Gen Genet 226, 167-176.

Lim, C.-J., Haller, B. \& Fuchs, J. A. (1985). Thioredoxin is the bacterial protein encoded by $f p$ that is required for filamentous bacteriophage $\mathrm{f} 1$ assembly. J Bacteriol 161, 799-802.

Maniatis, T., Fritsch, E. F. \& Sambrook, J. (1982). Molecular Cloning: a Laboratory Manual. Cold Spring Harbor, NY: Cold Spring Harbor Laboratory.

Mark, D. F. \& Richardson, C. C. (1976). Escherichia coli thioredoxin: a subunit of bacteriophage T7 DNA polymerase. Proc Natl Acad Sci USA 73, 780-784.

Miranda-Vizuete, A., Martinez-Galisteo, E., Åslund, F., LopezBarea, J., Pueyo, C. \& Holmgren, A. (1994). Null thioredoxin and glutaredoxin Escherichia coli K-12 mutants have no enhanced sensitivity to mutagens due to a new GSH-dependent hydrogen donor and high increases in ribonucleotide reductase activity. $J$. Biol. Chem. 269, 16631-16637.

Mitsui, A., Hirakawa, T. \& Yodoi, J. (1992). Reactive oxygenreducing and protein-refolding activities of adult $T$ cell leukemiaderived factor/human thioredoxin. Biochem Biophys Res Commun 186, 1220-1226.

Moskovitz, J., Rahman, M. A., Strassman, J., Yancey, S. O., Kushner, S. R., Brot, N. \& Weissbach, H. (1995). Escherichia coli peptide methionine sulfoxide reductase gene: regulation of expression and role in protecting against oxidative damage. $J$ Bacteriol 177, 502-507.

Muller, E. G. D. (1991). Thioredoxin deficiency in yeast prolongs $S$ phase and shortens the G1 interval of the cell cycle. J Biol Chem 266, 9194-9202.

Muller, E. G. D. (1994). Deoxyribonucleotides are maintained at normal levels in a yeast thioredoxin mutant defective in DNA synthesis. J Biol Chem 269, 24466-24471.

Muller, E. G. D. (1995). A redox-dependent function of thioredoxin is necessary to sustain a rapid rate of DNA synthesis in yeast. Arch Biochem Biophys 318, 356-361.

Muller, G. D. \& Buchanan, B. B. (1989). Thioredoxin is essential for photosynthetic growth. The thioredoxin $m$ gene of Anacystis nidulans. J Biol Chem 264, 4008-4014.

Nakamura, H., Matsuda, M., Furuke, K., Kitaoka, Y., Iwata, S., Toda, K., Inamoto, T., Yamaoka, Y., Ozawa, K. \& Yodoi, J. (1994). Adult $\mathrm{T}$ cell leukemia-derived factor/human thioredoxin protects endothelial F-2 cell injury caused by activated neutrophils or hydrogen peroxide. Immunol Lett 42, 75-80.

Natsuyama, S., Noda, Y., Narimoto, K., Umaoka, Y. \& Mori, T. (1992). Release of two-cell block by reduction of protein disulfide with thioredoxin from Escherichia coli in mice. J Reprod Fert 95, 649-656.

Okamoto, T., Ogiwara, H., Hayashi, T., Mitsui, A., Kawabe, T. \& Yodoi, J. (1992). Human thioredoxin/adult $T$ cell leukemiaderived factor activates the enhancer binding protein of human immunodeficiency virus type 1 by thiol redox control mechanism. Int Immunol 4, 811-819.

Pasternak, C., Assemat, K., Breton, A. M., Clément-Métral, J. D. \& Klug, G. (1996). Expression of the thioredoxin gene $(\operatorname{tr} x A)$ in 
Rhodobacter sphaeroides Y is regulated by oxygen. Mol Gen Genet 250, 189-196.

Pfennig, N \& Truper, H. G. (1974). The phototrophic bacteria. In Bergeys Manual of Determinative Bacteriology, pp. 24-75. Baltimore: Williams \& Wilkins.

Pille, S., Chuat, J. C., Breton, A. M., Clément-Métral, J. D. \& Galibert, F. (1990). Cloning, nucleotide sequence, and expression of the Rhodobacter sphaeroides $\mathrm{Y}$ thioredoxin gene. J Bacteriol 172, 1556-1561.

Pille, S., Assemat, K., Breton, A. M. \& Clément-Métral, J. D. (1996). The Gly74 Ser and Ser3 Ala mutations in Rhodobacter sphaeroides $\mathrm{Y}$ thioredoxin. Effects on active site reactivity and protein interaction. Eur J Biochem 235, 713-720.

Russel, M. \& Model, P. (1984). Characterization of the cloned fip gene and its product. $J$ Bacteriol 157, 526-532.

Russel, M. \& Model, P. (1985). Thioredoxin is required for filamentous phage assembly. Proc Natl Acad Sci USA 82, 29-33.

Russel, M. \& Model, P. (1986). The role of thioredoxin in filamentous phage assembly. J Biol Chem 261, 14997-15005.

Russel, M., Model, P. \& Holmgren, A. (1990). Thioredoxin or glutaredoxin in Escherichia coli is essential for sulfate reduction but not for deoxyribonucleotide synthesis. J Bacteriol 172, 1923-1929.

Salz, H. K., Flickinger, T. W., Mittendorf, E., Pellicena-Palle, A., Petschek, J. P. \& Albrecht, E. B. (1994). The Drosophila maternal effect locus deadhead encodes a thioredoxin homolog required for female meiosis and early embryonic development. Genetics 136, 1075-1086.

Schenk, H., Klein, M., Erdbrügger, W., Dröge, W. \& SchulzeOsthoff, K. (1994). Distinct effects of thioredoxin and antioxidants on the activation of transcription factors NF- $\kappa \mathrm{B}$ and AP1. Proc Natl Acad Sci USA 91, 1672-1676.
Simon, R., Priefer, U. \& Puhler, A. (1983). A broad host range mobilization system for in vivo genetic engineering: transposon mutagenesis in gram negative bacteria. Bio/Technology 1, 784-791.

Sistrom, W. R. (1977). Transfer of chromosomal genes mediated by plasmid R68.45 in Rhodopseudomonas sphaeroides. J Bacteriol 131, 526-532.

Sorachi, K.-I., Sugie, K., Maekawa, N., Takami, M., Kawabe, T., Kumagai, S., Imura, H. \& Yodoi, J. (1992). Induction and function of FceRII on YT cells; possible role of ADF/thioredoxin in FceRII expression. Immunobiol 185, 193-206.

Spector, A., Yan, G.-Z., Huang, R.-R. C., McDermott, M. J., Gascoyne, P. R. C. \& Pigiet, V. (1988). The effect of $\mathrm{H}_{2} \mathrm{O}_{2}$ upon thioredoxin-enriched lens epithelial cells. J Biol Chem 263, 4984-4990.

Toledano, M. B. \& Leonard, W. J. (1991). Modulation of transcription factor NF-kappa B binding activity by oxidationreduction in vitro. Proc Natl Acad Sci USA 88, 4328-4332.

Tomimoto, H., Akiguchi, I., Wakita, H., Kimura, J., Hori, K. \& Yodoi, J. (1993). Astroglial expression of ATL-derived factor, a human thioredoxin homologue, in the gerbil brain after transient global ischemia. Brain Res 625, 1-8.

Yanisch-Perron, C., Vieira, J. \& Messing, J. (1985). Improved M13 phage cloning vectors and host strains: nucleotide sequences of the M13mp18 and pUC19 vectors. Gene 33, 103-119.

Yen, H.-C. \& Marrs, B. (1977). Growth of Rhodopseudomonas capsulata under anaerobic dark conditions with dimethyl sulfoxide. Arch Biochem Biophys 181, 411-418.

Received 28 May 1996; revised 13 August 1996; accepted 19 August 1996. 